\title{
Research on Teaching Mode Reform of Applied University International Trade Major Based on Kolb's Experiential Learning Theory-- Skill Competition as the Driving Force
}

\author{
Suqing Xu \\ International Economics Department, Xi’an Fanyi University of Economics, Shaanxi, China
}

Keywords: Kolb’s experiential learning theory, international trade major, skill competition

\begin{abstract}
Kolb's experiential learning theory was proposed by Copper in 1984 based on the learning theory of experience. It divides the learning knowledge process into experience, reflection observation, abstract concept and active practice. In the teaching process of application-oriented university, emphasizing practical teaching can improve students' active learning consciousness. Moreover, it can create a practical environment for talent cultivation, enhance students' operational ability that will be able to adapt the job and meet social needs after graduation quickly. Therefore, this paper will study on teaching mode reform of international trade major in applied universities based on Kolb's experiential learning theory, so as to promote the teaching mode of international trade through the practical operation of skill competition.
\end{abstract}

\section{Introduction}

The international trade major is the advanced education discipline which is established for the training of excellent foreign trade talents. In the course of the development of China's foreign reform and opening-up for more than 30 years, the complex international rules have made our enterprises fail repeatedly in the international market competition. Therefore, the cultivation of excellent international trade talents has become one of the important subjects of the talents cultivation in colleges and universities. In the present international trade activities, there still lack of practical experience and poor practical ability. The newly hired international trade students cannot solve the practical problems of foreign trade for enterprises. They need a second job training. This situation is contrary to the purpose of application-oriented talents training in colleges and universities. Therefore, as the teaching mode of international trade in higher education, it aims to cultivate the practical operation ability and comprehensive business ability of foreign trade business. It is very important for the future career development of students majoring in international trade and the standardization of international trade market activities in China.

\section{Kolb's experiential learning theory}

\subsection{Kolb’s experiential learning definition}

Kolb's experiential emphasizes the process of experience learning. The continuous construction of the course enables the practice course to be reconstituted during the operation. Students can gain new knowledge by constantly reinventing the learning process. Kolb's experiential learning can create an independent learning environment for learners and provide a platform for learner innovation and development. The subjective thought is consistent with the objective experience, so as to facilitate the understanding and innovation of knowledge. Kolb's experiential learning is to transform learning experience into knowledge. Through the experience summarization, the knowledge of combining theory with practice can enhance learners' ability to use knowledge more flexible.

\subsection{Kolb’s experiential learning model}

Kolb’s experiential learning model is an adaptive ring structure composed with experience, 
reflection observation, abstract concept and active practice. New experiences and new knowledge are constantly generated in a circular pattern to ensure the sustainability of knowledge acquisition. The experience is experienced and mastered by participating in practical activities. Students can deep understand of knowledge, flexible use of knowledge, or creating new experiences through reflection and observation. By understanding and grasping the abstract generalization of knowledge and experience, students can form operational awareness, further gains the results of experience activities and learning knowledge. Through the behavior modification practice application, students will obtain the operation result. Moreover, through the result information feedback, we can get the physical examination, form the learning path of closed loop knowledge and experience, and form a spiral acquisition process of knowledge and experience.

\subsection{Characteristics of Kolb's experiential learning theory}

Kolb's experiential learning theory defines learning as a process. The constant unification and correction of knowledge and experience makes knowledge capable of sustaining sustainable growth. Learning is based on experience. Form effective exclusive knowledge through experience summary, and continuously obtain knowledge continuously. Test knowledge through practice and revise it, constantly improve the knowledge reserve and the ability to use the knowledge flexibly. Experience learning is a process of adapting to the environment and changing the environment. It can summarize experience through practical process and form theoretical guidance. This enables learning to accompany a person's life. Experience is the interaction between people, between people and things. In this process, interconnection, infiltration, influence and restriction are not transferred by individual will, and the combination of subjective thought and objective experience is emphasized. Through the experience learning, we can improve the ability of knowledge acquisition, solve new problems, and finally promote the innovation and development of knowledge.

\section{Present teaching situation of international trade in applied universities in China}

\subsection{Guided by traditional theory leads low students' practical level}

At present, the teaching mode of international trade in colleges and universities in our country still adopts classroom theoretical teaching. Although some schools have carried out the school-enterprise cooperation model under the impetus of teaching reform, they have invited enterprise experts to open classes in schools, the content of teaching is only on the surface phenomenon, which does not involve the core content due to the complexity of international trade in terms of norms, laws and operation methods. The cramming teaching method not only let the student feel learning difficulties and pressure, but also fail to fulfill the tasks assigned by the company due to lack of experience. Therefore, many foreign trade enterprises have independent post training system, or the cooperation with the society is mainly aimed at the secondary training of college graduates to meet the job requirements.

\subsection{The lack of teachers' practical experience leads poor teaching effect}

The professional teachers of international trade in colleges and universities are the subject teachers who are engaged in theoretical basic research for a long time. They are familiar with trade policies, laws and regulations and operating practices. However, the theoretical basis cannot be flexibly applied in a timely manner due to the lack of front-line work experience when facing the complex and volatile international trading environment. Some colleges and universities have hired the front-line personnel from outside enterprises to participate in the teaching of the school, which is only the explanation of individual cases. Students can't really get exercise. In addition, the school and the enterprise cooperation, will encourage the teacher to the foreign trade enterprise to take up the exercise. However, due to the lack of incentive system and the influence of enterprise business confidentiality, it is difficult for teachers to gain business promotion. Therefore, the teaching effect is affected by the lack of practical experience, which leads to the disconnection between the knowledge acquired by students and the actual business operation of the enterprise. 


\subsection{The simplification of practice teaching mode lead low enthusiasm of students}

The international trade major of applied university focuses on cultivating students' practical ability. Many universities have arranged practical courses for international trade students. However, based on the limited practice resources, the allocation proportion of class hours is very small, the university only arrange a practical training when nearly graduate. And the actual training program has been unchanged for many years, which leads to the disconnection between the practical training content and the practical application. From the practice teaching model of international trade in colleges and universities, it still focuses on teacher explanation, and the degree of students' participation in operation is very low. This kind of practice teaching mode has little difference with the classroom theory teaching, which leads to the students' lack of interest in learning, and makes the teaching effect not obvious.

\section{Promote the reform of international trade professional practice teaching with skill competition}

\subsection{Skill competition form promotes the reform of international trade professional practice teaching method}

We need to change the teaching method based on the case and increase the training of project situational simulation. Students are the subject of the subject, teachers are auxiliary. Students can understand the knowledge content through practice. Continuous innovation, with project orientation, flexible and varied learning styles, will integrate students into the training environment, stimulate students' creativity and competitive awareness. For example: design business negotiations, customs clearance operations, etc. In order to improve the simulation effect of skill competition, students are simulated by the actual operation process of existing enterprises. Adopt the model of team cooperation to design the work position and create the professional training atmosphere for students. It will enhance students' practical ability and cultivate students' interest in learning.

The project design of the skill competition is guided by Kolb's experiential learning theory. We can carry out modular training according to the requirement of foreign trade position skill. Each skill module designs a specific training program and sets the appropriate evaluation criteria. The students' learning ability and learning level are tested according to the students' completion status. For example, in the import and export contract training, the payment process of the payment process for the international trade process will be paid for competitive training. Set up two groups, one for importers and one for exporters. The simulation negotiations will eventually form the payment terms into the contract. Through this training, the students are clear about the import and export contract process, and summarize and digest the experience used in each link. They have a more intuitive and clear understanding of the specific operational skills, and then summarize the problems and deficiencies in the simulation process to form a learning process based on Kolb's experiential learning.

\subsection{Skills competition content promotes the teaching content reform of international trade professional practice}

Teaching content reform of international trade in applied universities changes the teaching content of traditional theoretical knowledge into the practical teaching content. Optimize course content and integrate into professional practice. Keep the theory close to the practical purpose of knowledge. In terms of skills competition, we should fully absorb the frontier technology of the industry. We can integrate technology into the training, and then divide the syllabus content to provide theoretical support for practical teaching. Objectively reflect the real work in international trade activities. The requirements for skills and experience are reflected in the competition content. Build a standardized assessment system and improve the pertinence of project assessment. Let the students master the specific work flow through the training competition, summarize and form the habit of self-growth through the continuous experience. For example, we can operate classified teaching of competition content. Such as import and export cost accounting competition, 
competition declaration, import and export commodity classification competition, import and export tax accounting competition, etc. This will standardize the students' operation behavior, so that the students' simulation training is closer to the actual needs, they can meet the employment standards of the enterprise.

\subsection{Skills competition promotes the in-depth cooperation of the international trade professional practice teaching}

School-enterprise cooperation has become an important way to cultivate talents in applied universities. Under the influence of market operation confidentiality and the resource specificity, the current school-enterprise cooperation exists only on the surface cooperation. This is not conducive to the cultivation of talents and the need of enterprises for talents. There must be an opportunity point to strengthen the in-depth cooperation between the school and enterprises. Skill competition has its own practicality and competitiveness. At this time, enterprises can be required to participate in the student skills competition guidance and comments. It can also be provided by enterprises, so that students can provide new ideas and methods for enterprises through skills competition and achieve win-win results between enterprises and schools. In the process, the content of competitive project matches the enterprise project. The position setting is relative to the enterprise, and the assessment standard is in accordance with the requirements of the enterprise. This enables students to enhance the competitiveness of employment in practical training activities. It also provides a direct window for enterprises to select excellent talents. It has realized the close contact between school and the enterprise, so that the school can continuously obtain the latest information of the enterprise market, as well as the qualified personnel training for the enterprise.

\section{Conclusions}

International trade is one of the important subjects of higher education. It takes the import and export trade negotiation as the main line. International business norms, laws and so on are applied curriculum content, talent training needs a lot of practice. This is consistent with Kolb's experiential learning theory, which is based on experience. Let the student grasp a comprehensive international trade procedures, familiar with relevant laws and regulations, and able to work out of the gate is the first place to reform the major teaching mode of international trade in the first place. Skills competition promotes practice teaching is the key discussion in this paper. This method can not only improve students' practical ability, but also stimulate students' interest in learning. It enables students to meet the requirements of a qualified foreign trade personnel, promote the development of the professional teaching reform, and improve education level of institutions of higher learning.

\section{Acknowledgements}

The study was supported by "Research on the reform of International Trade teaching mode in application oriented university from the perspective of Kolb's experiential learning theory -- taking skills competition as the driving force, China (Grant No. 13B28)”.

\section{References}

[1] Li Junzheng. Enlightenment of Kolb’s experiential learning theory to adult education [J] China Adult Education,2017(8):86-88

[2] Wu Xiaolin. Research on experimental teaching reform of international trade in technology applied universities [J] The southern Journal,2017(1):86-87

[3] Xu Qiong, Huang Guangqun. The Promotion of Vocational Skills Competition to the Practice Teaching Reform of International Trade Practice Course[J] Journal of Anhui Vocational College of Police Officers,2017(8):86-88 